\title{
Intraoperative Ultrasound in the Treatment of Breast Cancer
}

\author{
Intraoperative Sonografie in der Behandlung des Mammakarzinoms
}

Authors

Affiliations
H. Eggemann ${ }^{1 *}$, T. Ignatov ${ }^{1 *}$, A. Beni ${ }^{1}$, S. D. Costa ${ }^{1}$, O. Ortmann ${ }^{2}$, A. Ignatov ${ }^{1,2}$

${ }^{1}$ Unifrauenklinik, Magdeburg

${ }^{2}$ Lehrstuhl für Frauenheilkunde und Geburtshilfe der Uni Regensburg am Caritas-Krankenhaus St. Josef, Regensburg

\section{Key words \\ - breast cancer \\ - ultrasound \\ - gynaecology \\ Schlüsselwörter \\ - Mammakarzinom \\ - Ultraschall \\ - Frauenheilkunde}

Deutschsprachige Zusatzinformationen online abrufbar unter: www.thieme-connect.de/ ejournals/toc/gebfra received 22.4.2013

revised $\quad 17.6 .2013$

accepted 30.6.2013

\section{Bibliography}

DOI http://dx.doi.org/ 10.1055/s-0033-1350828

Geburtsh Frauenheilk 2013; 73 : 1028-1034 @ Georg Thieme

Verlag KG Stuttgart · New York . ISSN 0016-5751

\section{Correspondence}

Dr. Atanas Ignatov

Universitätsfrauenklinik

Magdeburg

Gerhard-Hauptmann-Straße 35

39108 Magdeburg

atanas.ignatov@gmail.com

\section{Abstract \\ $\nabla$}

Purpose: The aim of this study was to investigate the value of intraoperative ultrasound in breastconserving operations and to compare it with standard procedures.

Methods: For this purpose 307 women with palpable breast cancers and 116 patients with nonpalpable breast cancers were compared retrospectively. In the group with palpable breast cancers 177 patients were treated by US-guided operations and 130 patients underwent palpationguided breast-conserving operations. As primary outcomes, the resection margins and the rate of re-operations were evaluated.

Results: With regard to disease-free resection margins, intraoperative ultrasound was significantly superior to palpation alone. In the group of patients in whom the tumours were extirpated with the help of palpation, R1 resections were observed almost twice as often (16.9\%) as in the USguided group (8.5\%). In the group with non-palpable breast cancers, intraoperative ultrasound was employed in 61 patients. As a control, 43 cases were evaluated in whom the breast-conserving operation was performed after wire marking. In this group US-guided tumour removal proved to be superior to that after wire marking for tumours that did not exhibit any intraductal components. Otherwise the redo resection rate was reduced by use of ultrasound. Furthermore, the surgeon was able by means of intraoperative ultrasound to identify "problematic" margins and to excise them in the same sitting.

Conclusions: The US-guided, breast-conserving operations led to a lower rate of $\mathrm{R} 1$ resections and redo operations in comparison to operations with palpation alone or those after wire marking.

\section{Zusammenfassung \\ $\nabla$}

Ziel: Das Ziel dieser Studie war, den Stellenwert der intraoperativen Sonografie bei brusterhaltenden Operationen zu untersuchen und ihn mit den Standardverfahren zu vergleichen.

Methoden: Für diesen Zweck wurden 307 Frauen mit palpablen Mammakarzinomen und 116 Patientinnen mit nicht palpablen Mammakarzinomen retrospektiv untersucht. In der Gruppe der palpablen Mammakarzinome wurden $177 \mathrm{~Pa}-$ tientinnen mit US-gestützter und 130 Patientinnen mit palpationsgestützter brusterhaltender Operation behandelt. Als primäres Outcome wurden die Resektionsränder und die Rate der Nachoperationen evaluiert.

Ergebnisse: Im Hinblick auf freie Resektionsränder war die intraoperative Sonografie der alleinigen Palpation signifikant überlegen. In der Gruppe der Patientinnen, deren Tumor mithilfe der Palpation exzidiert worden ist, wurde eine R1-Resektion fast doppelt so häufig beobachtet (16,9\%) wie in der US-gestützten (8,5\%). In der Gruppe der nicht palpablen Mammakarzinome wurde die intraoperative Sonografie bei 61 Patientinnen angewendet. Als Kontrolle wurden 43 Fälle evaluiert, bei denen eine brusterhaltende Operation nach einer Drahtmarkierung durchgeführt wurde. In dieser Gruppe war die US-gestützte Tumorektomie der Tumorexzision nach Drahtmarkierung, für Tumore, die keine intraduktale Komponenten aufwiesen, überlegen. Sonst wurde die Nachresektionsrate durch die Sonografie reduziert. Zusätzlich war der Operateur in der Lage durch die Verwendung der intraoperativen Sonografie die „problematischen“ Ränder besser zu identifizieren und in der gleichen Sitzung zu resezieren. 
Rückschlüsse: Die US-gestützte brusterhaltende Operation führt im Vergleich zur alleinigen Palpation und der Operation nach Drahtmarkierung zur niedrigeren Rate an R1-Resektionen und Zweiteingriffen.

\section{Introduction}

\section{$\nabla$}

In the past two decades the breast-conserving operation (BCO) followed by adjuvant radiotherapy has become the standard treatment for breast cancer in early stages and is equally effective and safe as mastectomy [1,2]. The operation must effect tumour removal with disease-free margins. The rate of invasion of resection margins after a BCO is given as $5-60 \%$ in the literature [310]. Although the influence of positive resection margins on overall survival is still unclear, the R1 situation is one of the most important predictive factors for local recurrence [11,12].

Various methods are used to remove the tumour with diseasefree margins: radiological or, respectively, ultrasound wire marking (for non-palpable tumours), operations with palpation (for palpable tumours), intraoperative frozen section analysis $[9,10$, 13-16]. Ultrasound has been used successfully for many years in the diagnosis and monitoring of primary systemic therapy for breast cancer patients $[17,18]$. In contrast, intraoperative ultrasound during BCO was used as an alternative method to detect and remove non-palpable breast tumours for the first time at the end of the 1980s and beginning of the 1990s [19]. Subsequently, individual working groups checked the feasibility and safety of the technique as a localisation method. However, most studies included only very few patients. Accordingly the value of US-assisted BCO was a subject of controversial discussion [2028]. A Dutch group has evaluated the efficacy of the method for palpable breast cancers in a randomised, prospective study of 134 patients [29]. In this study it was found that US-guided BCO was associated with markedly fewer positive resection margins in comparison to BCO with palpation.

The aim of our study is to assess the value of intraoperative ultrasound in BCO. For this purpose we evaluated the safety of US-assisted tumourectomy in two groups of patients: i) those with palpable and ii) those with non-palpable breast cancers.

\section{Patients and Methods \\ $\nabla$}

\section{Patients}

All women with breast cancer who were treated by BCO in the Departments of Gynaecology and Obstetrics at the Universities of Magdeburg and Regensburg between 2000 and 2012 were eligible for this study. Only those patients were included for whom a preoperative histological confirmation was available and a complete and accurate documentation of the BCO was made with regard to the palpability of the tumour and the employed operative technique. Exclusion criteria were primary inoperable breast cancer, primary mastectomy, and incomplete surgical or pathological reports. In the study period, 423 patients fulfilled the above-mentioned requirements. 307 patients with palpable and 116 with non-palpable breast cancers were evaluated. In the $1 \mathrm{st}$ group we compared US-assisted tumourectomy with palpationassisted tumourectomy. In the second group, the patients were assessed in comparison to tumourectomy after wire marking. The palpability of the tumour was assessed prior to punch biopsy in order to exclude an influence of possible haematomas. The patients' characteristics are listed in Table 1.

\section{Group with palpable tumours}

The patients were grouped according to the localisation method. 177 (57.7\%) patients were treated by means of US-guided tumourectomy. 130 (42.3\%) patients were operated upon using palpation-guided tumourectomy. The completeness of tumour removal was assessed by touch and if the surgeon suspected an incomplete removal a second excision was undertaken.

In the US group intraoperative ultrasound was carried out using the US system Mikromaxx (Sonosite, Bothell, USA). Ultrasound scanning was performed prior to incision in lateromedial and craniocaudal directions. The resection margins were indicated using a sterile marker. After tumourectomy the surgeon performed an ex vivo sonography. The distance between the tumour and the resection margins was evaluated and suspicious margins were re-excised.

The median tumour size in both groups amounted to $16 \mathrm{~mm}$. The median excised volume in the palpation-guided tumourectomies was $101 \mathrm{~mm}^{3}$ and was comparable with the resection volume of $118 \mathrm{~mm}^{3}$ in the US-guided operations ( Table 1). Other patient and tumour characteristics were homogeneously distributed in both study groups.

The intraoperative ultrasound-guided tumourectomies of nonpalpable tumours were performed exclusively in the University Hospital Magdeburg. Wire marking has not been employed since 2008 and all cancers were removed after ultrasound localisation. On account of the retrospective nature of the study, approval from an ethics committee was not needed. Within the general contract conditions, $\S 16$, para 5 , the performance of purely retrospective studies after appropriate anonymisation is permitted.

\section{Group with non-palpable tumours}

$67(57.8 \%)$ of the non-palpable tumours were operated by means of intraoperative ultrasound-guided tumourectomy. These were compared with $49(42.2 \%)$ cases in which tumourectomy was performed after preoperative wire marking. The ultrasoundguided tumourectomies were performed as described above. In the other group, preoperative mammographically or, respectively, ultrasound-guided wire marking was employed. Postoperatively, the resected samples were examined by mammography or sonography outside of the operating theatre by a third person. In cases of suspected non-in-sano resection (R1), further resection was carried out in the same sitting.

The median tumour size amounted to 8 or, respectively, $10 \mathrm{~mm}$ for tumourectomies after wire marking or intraoperative ultrasound. The difference is not significant. The excised volumes also did not differ significantly between the two surgical techniques ( Table 1). With regard to the remaining tumour and patient characteristics the collective was uniform and homogeneous.

\section{Statistical analysis}

The statistical calculations were performed with the help of SPSS version 19.0 (SPSS, Chicago, Illinois, USA). Pearson's $X^{2}$ and Fisher's exact tests for categorical variables were used to identify cor- 
Table 1 Patient collective.

\begin{tabular}{|c|c|c|c|c|c|c|}
\hline Palpable & & & & Non-palpable & & \\
\hline Variable & $\begin{array}{l}\text { Palpation-assisted } \\
\text { n (\%) }\end{array}$ & $\begin{array}{l}\text { US-assisted } \\
\text { n (\%) }\end{array}$ & $\mathrm{p}$ value & $\begin{array}{l}\text { After wire marking } \\
\text { n (\%) }\end{array}$ & $\begin{array}{l}\text { US-assisted } \\
\text { n (\%) }\end{array}$ & p value \\
\hline Total & $130(42.3)$ & $177(57.7)$ & & & $49(42.2)$ & $67(57.8)$ \\
\hline Age, median & $63(25-94)$ & $57(29-85)$ & 0.072 & $63(26-79)$ & $61(26-83)$ & 0.363 \\
\hline Tumour size (mm) & $16(4-60)$ & $16(4-55)$ & 0.752 & $8(4-15)$ & $10(4-19)$ & 0.073 \\
\hline Excised volume $\left(\mathrm{mm}^{3}\right)$ & $101(27-637)$ & $118(39-569)$ & 0.397 & $81(13-352)$ & $84(18-280)$ & 0.585 \\
\hline Menopause & & & 0.102 & & & 0.274 \\
\hline - premenopausal & $24(18.5)$ & $47(26.6)$ & & $9(18.4)$ & $19(28.4)$ & \\
\hline - postmenopausal & $106(81.5)$ & $130(73.4)$ & & $40(81.6)$ & $48(71.6)$ & \\
\hline Lymph node status (N) & & & 0.249 & & & 0.759 \\
\hline - NO & $100(76.9)$ & $146(82.5)$ & & $43(87.8)$ & $61(91.0)$ & \\
\hline - N1 & $30(23.1)$ & $31(17.5)$ & & $6(12.2)$ & $6(9.0)$ & \\
\hline Histology & & & 0.353 & & & 0.917 \\
\hline - ductal & $108(83.1)$ & $157(88.7)$ & & $44(89.8)$ & $60(88.7)$ & \\
\hline - lobular & $13(10.0)$ & $11(6.2)$ & & $3(6.1)$ & $5(7.5)$ & \\
\hline D other & $9(6.9)$ & $9(5.1)$ & & $2(4.1)$ & $2(3.0)$ & \\
\hline Intraductal component & & & 0.610 & & & 0.111 \\
\hline no & 35 (26.9) & $53(29.9)$ & & $12(24.5)$ & $27(40.3)$ & \\
\hline - yes & $95(73.1)$ & $124(70.1)$ & & $37(75.5)$ & $40(59.7)$ & \\
\hline Grade (G) & & & 0.271 & & & 0.349 \\
\hline - G1 & $15(11.5)$ & $30(16.9)$ & & $7(14.3)$ & $16(23.9)$ & \\
\hline - $G 2$ & $85(65.4)$ & $101(57.1)$ & & $26(53.1)$ & $35(52.2)$ & \\
\hline - $\mathrm{G} 3$ & $30(23.1)$ & $46(26.0)$ & & $16(32.7)$ & $16(23.9)$ & \\
\hline OR status & & & 0.765 & & & 0.348 \\
\hline$>\mathrm{OR}-$ & $25(19.2)$ & $31(17.5)$ & & $12(24.5)$ & $11(16.4)$ & \\
\hline - $\mathrm{OR}+$ & $105(80.8)$ & $146(82.5)$ & & $37(75.5)$ & $56(83.6)$ & \\
\hline PR status & & & 0.708 & & & 0.245 \\
\hline - $\mathrm{PR}-$ & $42(32.3)$ & $53(29.9)$ & & $22(44.9)$ & $22(32.8)$ & \\
\hline - $\mathrm{PR}+$ & $88(67.7)$ & $124(70.1)$ & & $27(55.1)$ & $45(67.2)$ & \\
\hline Her 2 status & & & 0.859 & & & 0.262 \\
\hline > Her2- & $94(72.3)$ & $154(87.0)$ & & $35(71.4)$ & 60 (89.6) & \\
\hline - Her2+ & $15(11.5)$ & $23(13.0)$ & & $8(16.3)$ & $7(10.4)$ & \\
\hline - unknown & $21(16.2)$ & $0(0)$ & & $6(12.2)$ & $0(0)$ & \\
\hline
\end{tabular}

Her2: human epidermal growth factor receptor 2; OR: oestrogen receptor; PR: progesterone receptor; US: ultrasound

relations between the various clinico-pathological variables and the resection margins or, respectively, the re-excision rate and Student's t test was used for the continuous variables. A logistic regression analysis was performed for the multivariate analysis. Results were considered to be statistically significant at the level $\mathrm{p}<0.05$.

\section{Results}

Intraoperative ultrasound in palpable breast cancer

First of all the influence of the various localisation techniques on the surgical margins was investigated. From $\bullet$ Table 2 it is seen that US-guided tumourectomy is associated with a significantly lower rate $(\mathrm{p}=0.033)$ of infested margins $(\mathrm{R} 1)$ in comparison to the BCOs performed only with the aid of palpation. An R1 status was observed almost twice as frequently in the group of patients in whom the tumours were resected after palpation (16.9\%). The R1 rate for US-guided tumourectomies amounted to $8.5 \%$.

An $\mathrm{R} 1$ resection was observed significantly more frequently ( $p=0.0001$ or, respectively, $\mathrm{p}=0.033$; 0 Table 2 ) for lobular cancers and those exhibiting intraductal components. The intraductal components significantly reduce the sensitivity of intraoperative ultrasound $(\mathrm{p}=0.042)$. In $12(9.7 \%)$ of 124 cases, the resection margins were infested in the presence of an intraductal com- ponent and only in $1(1.9 \%)$ of 53 cases in the absence of an intraductal component. The median excised volume of tumours that were not completely removed from healthy tissue was significantly smaller $(p=0.013)$. The postmenopausal status as well as G2 tumours also showed a higher rate of infested surgical margins but this did not reach statistical significance. The age of the patient, the tumour, lymph node status, hormone receptor status and the Her2 status did not have an impact on the R status. The influence of clinico-pathological factors on the R status was examined by a multivariate analysis. The localisation method (HR 1.405; 95\% CI 1.246-1.564; $\mathrm{p}=0.025$ ) and the intraductal component (HR 0.865; 95\% CI 0.719-0.910; p=0.030) are the only factors that remained significant in the multivariate analysis.

Intraoperative ultrasound in non-palpable breast cancer Although the US-guided excision was associated with a lower rate of infected surgical margins for non-palpable tumours, the difference to tumour excision after wire marking was not statistically significant ( Table 3). When only tumours without intraductal components are considered, US-guided tumourectomy even shows a significant superiority to tumourectomy after wire marking. Interestingly, small, non-palpable tumours (median $6 \mathrm{~mm}$ ) were associated with a markedly higher rate of R1 resections, in comparison to larger tumours (median $10 \mathrm{~mm}$ ). Similar to the case with palpable breast cancers, the lobular type was also 
Table 2 Characterisation of the resection margins in cases with palpable breast cancers.

\begin{tabular}{|c|c|c|c|c|}
\hline Variable & $\begin{array}{l}\text { Total } \\
\text { (n) }\end{array}$ & $\begin{array}{l}\text { RO } \\
\text { n (\%) }\end{array}$ & $\begin{array}{l}\text { R1 } \\
\text { n (\%) }\end{array}$ & $\begin{array}{l}\mathrm{P} \\
\text { value }\end{array}$ \\
\hline Surgical method & & & & 0.033 \\
\hline - palpation-guided & 130 & $108(83.1)$ & $22(16.9)$ & \\
\hline - US-guided & 177 & $162(91.5)$ & $15(8.5)$ & \\
\hline Age, median & 307 & $59(25-94)$ & $63(30-86)$ & 0.159 \\
\hline Menopause & & & & 0.063 \\
\hline - premenopausal & 71 & $67(94.4)$ & $4(5.6)$ & \\
\hline - postmenopausal & 263 & $203(86.0)$ & $22(14.0)$ & \\
\hline Tumour size (mm) & 307 & $16(5-54)$ & $15(5-60)$ & 0.237 \\
\hline $\begin{array}{l}\text { Excised volume } \\
\left(\mathrm{mm}^{3}\right)\end{array}$ & 307 & $\begin{array}{l}118 \\
(27-637)\end{array}$ & $\begin{array}{l}75 \\
(29-352)\end{array}$ & 0.013 \\
\hline $\begin{array}{l}\text { Lymph node status } \\
\text { (N) }\end{array}$ & & & & 0.124 \\
\hline - NO & 246 & $220(89.4)$ & $26(10.6)$ & \\
\hline - N1 & 61 & $50(82.0)$ & $11(18.0)$ & \\
\hline Histology & & & & 0.0001 \\
\hline - ductal & 265 & $238(89.8)$ & $27(10.2)$ & \\
\hline - lobular & 24 & $15(62.5)$ & $9(37.5)$ & \\
\hline others & 18 & $17(94.4)$ & $1(5.6)$ & \\
\hline $\begin{array}{l}\text { Intraductal } \\
\text { component }\end{array}$ & & & & 0.033 \\
\hline$>$ no & 88 & $83(94.3)$ & $5(5.7)$ & \\
\hline$\checkmark$ yes & 219 & $187(85,4)$ & $32(14,6)$ & \\
\hline Grade (G) & & & & 0.062 \\
\hline > $\mathrm{G} 1$ & 45 & $42(93.3)$ & $3(6.7)$ & \\
\hline > G2 & 186 & $15784.4)$ & $29(15.6)$ & \\
\hline - G3 & 76 & $71(93.4)$ & $5(6.6)$ & \\
\hline OR status & & & & 0.824 \\
\hline$>\mathrm{OR}-$ & 56 & $50(89.3)$ & $6(10.7)$ & \\
\hline - $\mathrm{OR}+$ & 251 & $220(87.6)$ & $31(12.4)$ & \\
\hline PR status & & & & 0.188 \\
\hline$>\mathrm{PR}-$ & 95 & $80(84.2)$ & $15(15,8)$ & \\
\hline > $\mathrm{PR}+$ & 212 & $190(89.6)$ & $22(10.4)$ & \\
\hline Her2 status & & & & 0.580 \\
\hline > Her2- & 248 & $222(89.5)$ & $26(10.5)$ & \\
\hline - Her2+ & 38 & $33(86.8)$ & $5(13.2)$ & \\
\hline
\end{tabular}

Her2: human epidermal growth factor receptor 2; OR: oestrogen receptor; PR: progesterone receptor; R: resection status; US: ultrasound

a risk factor for an $\mathrm{R} 1$ resection $(\mathrm{p}=0.001)$. The other patient and tumour characteristics did not show any relationships with resection status. In the multivariate analysis, the menopausal status showed a significant impact on the resection margins (HR 1.038; 95\% CI 1.010-1.242; $\mathrm{p}=0.039$ ), as did the histological type (HR 1.583; 95\% CI 1.349-1.818; $\mathrm{p}=0.001$ ) and the tumour size (HR 6.583; 95\% CI 5.035-8.131; $\mathrm{p}<0.0001$ ).

\section{Intraoperative re-excision rate}

\section{and comparison to second operation}

Data on intraoperative re-excisions were examined in dependence on the localisation technique. As mentioned above, intraoperative re-excisions in US-guided tumourectomy were done when there was a sonographic suspicion of an $\mathrm{R} 1$ resection. In the control group re-excisions were performed after palpation of the tumour cavity or after radiographic or ultrasound examination of the resected tissue by a third person and not by the gynaecologist him/herself. In both groups intraoperative ultrasound led to a markedly lower rate of intraoperative re-excisions ( Table 4), although the difference appeared to be significant
Table 3 Characterisation of the resection margins in non-palpable breast cancers.

\begin{tabular}{|c|c|c|c|c|}
\hline Variable & $\begin{array}{l}\text { Total } \\
\text { (n) }\end{array}$ & $\begin{array}{l}\text { RO } \\
\text { n (\%) }\end{array}$ & $\begin{array}{l}\text { R1 } \\
\text { n (\%) }\end{array}$ & $\begin{array}{l}\mathrm{P} \\
\text { value }\end{array}$ \\
\hline Surgical method & & & & 0.759 \\
\hline $\begin{array}{l}\text { after wire } \\
\text { marking }\end{array}$ & 49 & $43(87.8)$ & $6(12.2)$ & \\
\hline - US-guided & 67 & $61(91.0)$ & $6(9.0)$ & \\
\hline Age, median & 116 & $61(26-83)$ & $65(51-74)$ & 0.191 \\
\hline Menopause & & & & 0.067 \\
\hline premenopausal & 28 & $28(100)$ & $0(0.0)$ & \\
\hline - postmenopausal & 88 & $76(86.4)$ & $12(13.6)$ & \\
\hline Tumour size (mm) & 116 & $\begin{array}{l}10 \\
(5-19 \mathrm{~mm})\end{array}$ & $\begin{array}{l}6 \\
(4-11 \mathrm{~mm})\end{array}$ & 0.001 \\
\hline $\begin{array}{l}\text { Excised volume } \\
\left(\mathrm{mm}^{3}\right)\end{array}$ & 116 & $\begin{array}{l}82(13- \\
\left.280 \mathrm{~mm}^{3}\right)\end{array}$ & $\begin{array}{l}68(30- \\
\left.352 \mathrm{~mm}^{3}\right)\end{array}$ & 0.417 \\
\hline $\begin{array}{l}\text { Lymph node status } \\
\text { (N) }\end{array}$ & & & & 1.000 \\
\hline NO & 104 & $93(89.4)$ & $11(10.6)$ & \\
\hline - N1 & 12 & $11(91.7)$ & $1(8.3)$ & \\
\hline Histology & & & & 0,001 \\
\hline - ductal & 104 & $97(93.3)$ & $7(6.7)$ & \\
\hline - lobular & 8 & $5(62.5)$ & $3(37.5)$ & \\
\hline others & 4 & $2(50.0)$ & $2(50.0)$ & \\
\hline $\begin{array}{l}\text { Intraductal } \\
\text { components }\end{array}$ & & & & 0.333 \\
\hline$>$ no & 39 & 37 (94.9) & $2(5.1)$ & \\
\hline - yes & 77 & $67(87.0)$ & $10(13.0)$ & \\
\hline Grade (G) & & & & 0.078 \\
\hline$>\mathrm{G} 1$ & 23 & $22(95.7)$ & $1(4.3)$ & \\
\hline$>G 2$ & 61 & $51(83.6)$ & $10(16.4)$ & \\
\hline$>\mathrm{G} 3$ & 32 & 31 (96.9) & $1(3.1)$ & \\
\hline OR status & & & & 1.000 \\
\hline$>\mathrm{OR}-$ & 23 & $21(91.3)$ & $2(8.7)$ & \\
\hline$\rightarrow \mathrm{OR}+$ & 93 & $83(89.2)$ & $10(10.8)$ & \\
\hline PR status & & & & 1.000 \\
\hline - $\mathrm{PR}-$ & 44 & 40 (90.9) & $4(9.1)$ & \\
\hline - $\mathrm{PR}+$ & 72 & 64 (88.9) & $8(11.1)$ & \\
\hline Her2 status & & & & 0.539 \\
\hline - Her2 - & 95 & 85 (89.5) & $10(10.5)$ & \\
\hline - Her2 + & 15 & $14(93.3)$ & $1(6.7)$ & \\
\hline
\end{tabular}

Her2: human epidermal growth factor receptor 2; OR: oestrogen receptor; PR: progesterone receptor; R: resection status; US: ultrasound

only for palpable tumours. In the cases with these palpable tumours an intraoperative re-excision after intraoperative ultrasound was performed in 21 of altogether 177 (11.9\%) patients as well as in 38 of 130 (29.2\%) patients after palpation. In the cases with non-palpable tumours a re-excision indicated by ultrasound was done in merely $7.5 \%$ of the patients, this was markedly lower than the re-excision rate of $20.4 \%$ after radiography of the resected sample.

Intraoperative ultrasound can also identify "problematic" margins with higher precision. The ultrasound-guided intraoperative re-excisions were performed in the correct direction in $87.5 \%$ of the cases with palpable tumours and in $100 \%$ of those with nonpalpable tumours ( Table 4). In contrast, the intraoperative reexcisions in cases with palpation as localisation method (for palpable tumours) and those with wire marking (for non-palpable tumours) were rarely performed in the correct direction, namely for $18.4 \%$ and, respectively, $30 \%$ of the patients. Thus it is concluded that most of the intraoperative re-excisions in these two groups were ineffective. 
Table 4 Localisation method and re-excision rate.

\begin{tabular}{|c|c|c|c|c|c|c|}
\hline \multirow[b]{2}{*}{ Variable } & \multicolumn{3}{|c|}{ Palpable breast cancer } & \multicolumn{3}{|c|}{ Non-palpable breast cancer } \\
\hline & $\begin{array}{l}\text { Palpation-guided } \\
\text { n (\%) }\end{array}$ & $\begin{array}{l}\text { US-guided } \\
\text { n (\%) }\end{array}$ & p value & $\begin{array}{l}\text { After wire marking } \\
\text { n (\%) }\end{array}$ & $\begin{array}{l}\text { US-guided } \\
\text { n (\%) }\end{array}$ & p value \\
\hline Intraoperative re-excision & 38 of $130(29.2)$ & 21 of $177(11.9)$ & 0.0001 & 10 of $49(20.4)$ & 5 of $67(7.5)$ & 0.051 \\
\hline $\begin{array}{l}\text { Intraoperative re-excision } \\
\text { in the "correct" direction }\end{array}$ & 7 of $38(18.4)$ & 18 of $21(85.7)$ & 0.0001 & 3 of $10(30 \%)$ & 5 of $5(100)$ & 0.006 \\
\hline Re-excision in 2nd session & 20 of $130(15.4)$ & 13 of $177(7.3)$ & 0.039 & 6 of $49(12.2)$ & 4 of $67(6.0)$ & 0.319 \\
\hline
\end{tabular}

In addition, intraoperative ultrasound also reduces the rate of second operations. In cases with palpable tumours, a second operation is necessary twice as often when the tumourectomy is performed with palpation (15.4\%) than for tumourectomies that have been performed with intraoperative ultrasound (7.3\%). The difference is statistically significant. In cases of non-palpable breast cancer the re-excision rate in a second session was markedly reduced by intraoperative ultrasound in comparison to the wire marking technique, namely 6.0 and $12.2 \%$, respectively. The difference is not statistically significant.

\section{Discussion}

\section{$\nabla$}

BCO in combination with adjuvant radiotherapy of the remaining breast tissue is currently the standard treatment for early breast cancer and is as effective and safe as mastectomy [1,2]. The greatest challenge for the surgeon, however, remains the achievement of disease-free margins [11]. In the case of positive resection margins (R1) a re-excision or a mastectomy must be performed $[30,31]$. Thus, the first operation should result in an $\mathrm{R} 0$ resection in order to reduce the rate of re-excisions or, respectively, to avoid local recurrences.

A promising method to achieve disease-free margins is intraoperative ultrasound. However, the method has not been sufficiently evaluated as yet. Initially breast ultrasound was used mainly for diagnostic purposes and for US-guided biopsies [17, 18]. Later it was shown that ultrasound can also be employed for the diagnosis of breast cancers that cannot be detected by mammography [32]. Furthermore, is has been demonstrated that the accurate estimation of tumour size prior to surgery is a significant predictive factor for re-operations [33]. Underestimation of tumour size is associated with an elevated risk for a follow-up excision [33]. Towards the end of the 1980s Schwartz and co-workers employed intraoperative ultrasound as an alternative method to detect and remove non-palpable breast tumours [19]. Subsequently the feasibility and safety of the method and its superiority over the classical lumpectomy after wire marking were investigated $[26,27,34,35]$. In further studies, improved surgical results obtained from the combination of intraoperative breast ultrasound and wire marking were reported [36].

Even so, the data from the available publications are a subject of controversy and are based on very small patient collectives. Only few reports exist on the use of US-guided tumour resection for palpable breast cancers. The fact that all palpable breast cancers can be visualised by ultrasound [37] makes it an excellent tool for the intraoperative localisation of these tumours. Nowadays nonpalpable tumours are usually marked by wire with the help of preoperative mammography or ultrasound. Tumourectomy of palpable tumour is based on palpation by the surgeon. Use of intraoperative ultrasound enables the surgeon to have a continu- ous and immediately available control of the tumourectomy. Earlier studies had even demonstrated that US-guided tumourectomy could improve the cosmetic results and patient satisfaction [22-25]. Although the use of intraoperative ultrasound in BCO is still a subject of highly controversial discussion, most studies show its superiority over palpation-guided tumourectomy or, respectively, tumourectomy after wire marking for both palpable and non-palpable tumours [21,22,24,25]. This superiority was recently demonstrated in a prospective, randomised study of 134 patients with palpable breast cancers [29]. In agreement with these data, we have found that US-guided lumpectomy of palpable breast cancers is associated with markedly reduced rates of R1 resections and follow-up operations. It is clearly superior to palpation-guided tumourectomy. For non-palpable tumours, the intraoperative use of ultrasound is only superior to the classical lumpectomy after wire marking when the tumour does not exhibit any intraductal components. This is reasonable since, in general, intraductal components cannot be detected by sonography. In our study, the resected volumes were not relevantly larger than the resected volumes from standard methods and were comparable with those of other studies [24,29].

In most cases positive margins are caused by an intraductal component, especially in the case of palpable tumours that often exhibit pronounced intraductal components [38]. The relationship between in-situ components and an increase in the number of positive surgical margins is well documented [39] and compatible with our data. On the other hand, it has also been reported that carcinoma-associated intraductal components are not relatively associated with positive margins in cases of US-guided tumourectomies $[3,23,24,29]$. This discrepancy to our data may lie in the small number of examined patients in the other studies or in the high rate of intraductal components in our patient collective.

Intraoperative ultrasound is able to minimise the R1 status and thus to reduce the re-excision rates in second operations, which is in accord with other publications $[24,26,27,29]$. Furthermore, it is possible with the help of intraoperative ultrasound to more easily identify "problematic" margins and so to perform the intraoperative re-excisions in the correct direction. In a study with markedly less patients, Olsha and co-workers achieved similar results [25]. The low accuracy of tumour localisation by palpation alone could explain that fact that dense mammary glands or benign changes such as fibrosis or mastopathy may limit detection by the surgeon. This is supported by the fact that in intraoperative re-excisions indicated by palpation, mastopathy tissue could be detected (data not shown). It is also well established that the mammographic density of the mammary glands has a significant influence on the re-excision rate in BCO [40]. Accordingly ultrasound localisation and evaluation of resection margins may be advantageous for patients with dense breasts. 
In summary, the intraoperative use of ultrasound enables the surgeon to directly assess the surgical margins and, if necessary, to undertake a re-excision in the correct direction which will then result in a lower number of second operations. Intraoperative ultrasound is a simple, non-traumatic, procedure that does not take up much time and is easy to perform [41,42]. In many centres preoperative ultrasound is performed outside the operating theatre. The tumour location is indicated by skin marking. The sole advantage of this procedure is the intraoperative saving of time, especially when operating capacity is limited, but it does depend on the presence of additional personnel. However, performance of ultrasound by the surgeon him/herself is advantageous as this gives him/her a better impression of the localisation and depth of the tumour. In this way also it is possible at any time to check the position of the tumour, thus making a more accurate planning of the course of the incision possible. Last but not least, the surgeon does not have to depend on other people.

The strengths of the present study lie in the size of the examined collective, the investigation of both palpable and non-palpable tumours and the well balanced patient and tumour characteristics in the study groups. Limitations of our study are: (i) all the disadvantages of a retrospective study; (ii) the compared groups contained different numbers of subjects; (iii) the cosmetic results and patient satisfaction were not studied.

\section{Acknowledgements}

\section{$\nabla$}

We are grateful to all the nursing personnel of the Department of Surgical Gynaecology in the Clinic for Gynaecology and Obstetrics of Magdeburg University and the Clinic for Gynaecology and Obstetrics of Regensburg University for their excellent help.

\section{Conflict of Interest}

\section{$\nabla$}

The authors declare that they have no conflicts of interest.

\section{References}

1 Fisher B, Anderson S, Bryant J et al. Twenty-year follow-up of a randomized trial comparing total mastectomy, lumpectomy, and lumpectomy plus irradiation for the treatment of invasive breast cancer. $\mathrm{N}$ Engl J Med 2002; 347: 1233-1241

2 Veronesi U, Cascinelli N, Mariani L et al. Twenty-year follow-up of a randomized study comparing breast-conserving surgery with radical mastectomy for early breast cancer. N Engl J Med 2002; 347: 12271232

3 Anscher MS, Jones P, Prosnitz LR et al. Local failure and margin status in early-stage breast carcinoma treated with conservation surgery and radiation therapy. Ann Surg 1993; 218: 22-28

4 Atkins D, Reiffen KA, Tegtmeier CL et al. Immunohistochemical detection of EGFR in paraffin-embedded tumor tissues: variation in staining intensity due to choice of fixative and storage time of tissue sections. J Histochem Cytochem 2004; 52: 893-901

5 Heimann R, Powers C, Halpem HJ et al. Breast preservation in stage I and II carcinoma of the breast. The University of Chicago experience. Cancer 1996; 78: 1722-1730

6 Jenkinson AD, Al Mufti RA, Mohsen Y et al. Does intraductal breast cancer spread in a segmental distribution? An analysis of residual tumour burden following segmental mastectomy using tumour bed biopsies. Eur J Surg Oncol 2001; 27: 21-25

7 Ohsumi S, Sakamoto G, Takashima S et al. Long-term results of breastconserving treatment for early-stage breast cancer in Japanese women from multicenter investigation. Jpn J Clin Oncol 2003; 33: 61-67
8 Park CC, Mitsumori M, Nixon A et al. Outcome at 8 years after breastconserving surgery and radiation therapy for invasive breast cancer: influence of margin status and systemic therapy on local recurrence. J Clin Oncol 2000; 18: 1668-1675

9 Pleijhuis RG, Graafland $M$, de Vries J et al. Obtaining adequate surgical margins in breast-conserving therapy for patients with early-stage breast cancer: current modalities and future directions. Ann Surg Oncol 2009; 16: 2717-2730

10 Waljee JF, Hu ES, Newman LA et al. Predictors of re-excision among women undergoing breast-conserving surgery for cancer. Ann Surg Oncol 2008; 15: 1297-1303

11 Luini A, Rososchansky J, Gatti G et al. The surgical margin status after breast-conserving surgery: discussion of an open issue. Breast Cancer Res Treat 2009; 113: 397-402

12 Dieterich $M$, Dieterich $H$, Moch $H$. Re-excision rates and local recurrence in breast cancer patients undergoing breast conserving therapy. Geburtsh Frauenheilk 2012; 72: 1018-1023

13 Atkins D, Reiffen KA, Tegtmeier CL et al. Immunohistochemical detection of EGFR in paraffin-embedded tumor tissues: variation in staining intensity due to choice of fixative and storage time of tissue sections. J Histochem Cytochem 2004; 52: 893-901

14 Lovrics PJ, Cornacchi SD, Vora R et al. Systematic review of radioguided surgery for non-palpable breast cancer. Eur J Surg Oncol 2011; 37: 388-397

15 Luini A, Zurrida S, Paganelli G et al. Comparison of radioguided excision with wire localization of occult breast lesions. Br J Surg 1999; 86: $522-$ 525

16 Rovera F, Frattini F, Marelli M et al. Radio-guided occult lesion localization versus wire-guided localization in non-palpable breast lesions. Int J Surg 2008; 6 (Suppl. 1): S101-S103

17 Fornage BD, Sneige N, Edeiken BS. Interventional breast sonography. Eur J Radiol 2002; 42: 17-31

18 Nurko J, Edwards MJ. Image-guided breast surgery. Am J Surg 2005; 190: 221-227

19 Schwartz GF, Goldberg BB, Rifkin MD et al. Ultrasonography: an alternative to $\mathrm{X}$-ray-guided needle localization of nonpalpable breast masses. Surgery 1988; 104: 870-873

20 Tamoxifen for early breast cancer: an overview of the randomised trials. Early Breast Cancer Trialists' Collaborative Group. Lancet 1998; 351: $1451-1467$

21 Davis KM, Hsu CH, Bouton ME et al. Intraoperative ultrasound can decrease the re-excision lumpectomy rate in patients with palpable breast cancers. Am Surg 2011; 77: 720-725

22 Fisher CS, Mushawah FA, Cyr AE et al. Ultrasound-guided lumpectomy for palpable breast cancers. Ann Surg Oncol 2011; 18: 3198-3203

23 Krekel N, Zonderhuis B, Muller S et al. Excessive resections in breastconserving surgery: a retrospective multicentre study. Breast J 2011; 17: 602-609

24 Moore MM, Whitney LA, Cerilli L et al. Intraoperative ultrasound is associated with clear lumpectomy margins for palpable infiltrating ductal breast cancer. Ann Surg 2001; 233: 761-768

25 Olsha 0 , Shemesh $D$, Carmon $M$ et al. Resection margins in ultrasoundguided breast-conserving surgery. Ann Surg Oncol 2011; 18: 447-452

26 Rahusen FD, Taets van Amerongen AH, van Diest PJ et al. Ultrasoundguided lumpectomy of nonpalpable breast cancers: a feasibility study looking at the accuracy of obtained margins. J Surg Oncol 1999; 72: 72-76

27 Rahusen FD, Bremers AJ, Fabry HF et al. Ultrasound-guided lumpectomy of nonpalpable breast cancer versus wire-guided resection: a randomized clinical trial. Ann Surg Oncol 2002; 9: 994-998

28 Rubio IT, Henry-Tillman R, Klimberg VS. Surgical use of breast ultrasound. Surg Clin North Am 2003; 83: 771-788

29 Krekel NM, Haloua MH, Lopes Cardozo AM et al. Intraoperative ultrasound guidance for palpable breast cancer excision (COBALT trial): a multicentre, randomised controlled trial. Lancet Oncol 2013; 14: 4854

30 Kaufmann M, Morrow M, von Minckwitz G et al. Locoregional treatment of primary breast cancer: consensus recommendations from an International Expert Panel. Cancer 2010; 116: 1184-1191

31 Morrow M. Trends in the surgical treatment of breast cancer. Breast J 2010; 16 (Suppl. 1): S17-S19

32 Kolb TM, Lichy J, Newhouse JH. Occult cancer in women with dense breasts: detection with screening US - diagnostic yield and tumor characteristics. Radiology 1998; 207: 191-199 
33 Meier-Meitinger M, Rauh C, Adamietz B et al. Accuracy of radiological tumour size assessment and the risk for re-excision in a cohort of primary breast cancer patients. Eur J Surg Oncol 2012; 38: 44-51

34 Harlow SP, Krag DN, Ames SE et al. Intraoperative ultrasound localization to guide surgical excision of nonpalpable breast carcinoma. J Am Coll Surg 1999; 189: 241-246

35 Kaufman CS, Jacobson L, Bachman B et al. Intraoperative ultrasound facilitates surgery for early breast cancer. Ann Surg Oncol 2002; 9: 988993

36 Bouton ME, Wilhelmson KL, Komenaka IK. Intraoperative ultrasound can facilitate the wire guided breast procedure for mammographic abnormalities. Am Surg 2011; 77: 640-646

37 Georgian-Smith D, Taylor KJ, Madjar $H$ et al. Sonography of palpable breast cancer. J Clin Ultrasound 2000; 28: 211-216
38 Tresserra F, Feu J, Grases PJ et al. Assessment of breast cancer size: sonographic and pathologic correlation. J Clin Ultrasound 1999; 27: 485491

39 Borger J, Kemperman H, Hart A et al. Risk factors in breast-conservation therapy. J Clin Oncol 1994; 12: 653-660

40 Bani MR, Lux MP, Heusinger $K$ et al. Factors correlating with reexcision after breast-conserving therapy. Eur J Surg Oncol 2009; 35: 32-37

41 Donaldson LA, Cliff A, Gardiner L et al. Surgeon-controlled ultrasoundguided core biopsies in the breast - a prospective study and a new use for surgeons in the clinic. Eur J Surg Oncol 2003; 29: 139-142

42 Staren ED, Knudson MM, Rozycki GS et al. An evaluation of the American College of Surgeons' ultrasound education program. Am J Surg 2006; 191: 489-496 